\title{
Nevrom i klitoris etter omskjæring
}

\author{
Omskjæring av kvinner er et inngrep uten medisinsk indikasjon. Det har ofte senfølger. Vi vil presentere \\ et tilfelle av traumatisk nevrom etter omskjæring. Dette er en sjeldent rapportert komplikasjon som trolig \\ er underrepresentert i litteraturen.
}

Pasienten. En ung og generelt frisk kvinne, født og oppvokst i Afrika, ble henvist pga. $ø$ øende plager fra en øm oppdrivning i klitorisområdet. Hun var blitt omskåret i tenårene og fikk tre år senere fjernet en kul fra klitorisområdet ved et lokalsykehus i hjemlandet. Det oppsto da alvorlig blødning og postoperativ infeksjon. Hun beskrev kulen som 2-3 cm stor. Den ble ikke undersøkt histologisk. Om lag to år etter operasjonen utviklet hun så gradvis en ny kul i samme område. Den ga lokal ømhet, hindret bruk av stramme klær og var smertefull ved samleie og annen berøring. Etter ytterligere to år kom pasienten til oss for vurdering.

Ved undersøkelse manglet klitoris og frenulum, men labiae minora og majora var intakte, og introitus og vagina var normalt dimensjonert. Genitalia interna var normale. Over mons pubis var det et $6 \mathrm{~cm}$ langt bredt og ujevnt arr som strakte seg oppover i midtlinjen fra fremre del av introitus. I dypet under arret kunne det palperes en ca. $2 \mathrm{~cm}$ stor, øm tumor som kunne forskyves litt, men som virket adherent mot underlaget. Lokaliseringen tilsa at tumor hadde med omskjæringen eller det senere inngrepet å gjøre. Av differensialdiagnoser tenkte vi pà subkutan cyste, fibrom, abscess, aterom eller en tumor av et eller annet slag.

Ved kirurgisk eksplorasjon fant vi en hvitlig, relativt velavgrenset tumor som utgikk fra eller var adherent til en struktur vi oppfattet som restene av klitoris. Tumor var $1,5 \mathrm{~cm}$ stor og ble ekstirpert. Histologisk undersøkelse viste traumatisk nevrom (fig 1). Det postoperative forløpet var ukomplisert. Senere har kvinnen hatt en viss grad av vedvarende ømhet $i$ området, men uten at det har vært mulig å påvise residiv av tumor ved palpasjon, ultralyd-eller MR-undersøkelse. Hun kan gjennomføre samleie uten smerte.

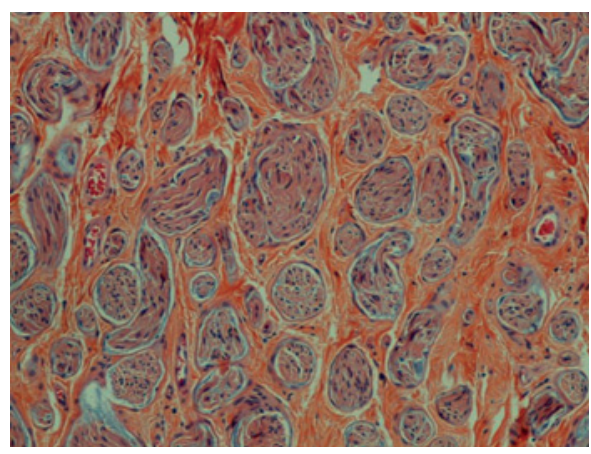

Figur 1 Multiple prolifererende nervefasikler med omkringliggende kompakt kollagen

\section{Omskjæring av kvinner}

Omskjæring av kvinner (female genital mutilation) er en gammel og utbredt tradisjon som i hovedsak praktiseres i afrikanske land. WHO estimerer at det $\mathrm{i}$ dag lever 100-140 millioner jenter og kvinner som er omskåret (1). I tillegg til fysisk smerte og psykisk lidelse er omskjæring av kvinner forbundet med mange komplikasjoner (1-3). Emnet ble omtalt i Tidsskriftet i 2006 (3).

Akutte komplikasjoner er sjokk, livstruende blødning, sårinfeksjon, sepsis, skade på nærliggende organer (urethra, blære, vagina, rectum, Bartholins kjertel) samt frakturer - fordi pasienten holdes fast med makt under inngrepet. Mange utvikler kroniske plager som dysmenoré, dysuri, residiverende urinveisinfeksjoner, hematokolpos, inklusjonscyster i arret, seksuelle problemer, infertilitet, fødselskomplikasjoner samt komplikasjoner knyttet til senere rekonstruktiv kirurgi $(1,3)$. Det finnes ingen pålitelig statistikk over forekomsten av de forskjellige komplikasjonene, da de fleste oppstår i land der slik statistikk ikke føres. Tumorutvikling etter omskjæring synes å være en sjeldenhet, men forekommer kanskje hyppigst i form av epidermale inklusjonscyster $(4,5)$.

\section{Nervesvulster i vulva}

Nervesvulster i vulva forekommer sjelden og opptrer helst som ledd i nevrofibromatose (von Recklinghausens sykdom) $(6,7)$, som i Norge har en insidens på ca. 15 per år (8). Det var ingen mistanke om nevrofibromatose hos vår pasient eller i hennes familie.

Nevrom lokalisert til klitoris er svært sjeldent. Kun ti tilfeller er til nå publisert på verdensbasis $(6,7,9-16)$, hvorav kun ett som komplikasjon til omskjæring (6).

Traumatisk nevrom er ikke en egentlig neoplasme, det representerer en nervesvulst som oppstår pga. atypisk proliferasjon av regenererende nervefibre som følge av nerveskade. Traumatisk nevrom kan oppstå i alle organer der nerver skades. Malign transformasjon er ikke beskrevet. Kun fire tilfeller av traumatisk nevrom i vulva er tidligere publisert: ett som komplikasjon etter omskjæring (6), ett etter traume mot labium minus $(17)$ og to i episiotomiarr $(18,19)$.

Behandling av nevromer er kirurgisk fjerning, gjerne med forsenking av nerveenden for å hindre residiv (20). Det foreligger ingen tall for residivrisiko. Hos vår pasient ble en tumor som formodentlig var et nevrom, fjernet tre år etter omskjæringen, og et sikkert nevrom fjernet fire år etter dette.

Med tanke på det store antall kvinner som utsettes for omskjæring, er traumatisk nevrom i vulva trolig underrepresentert i litteraturen. Med økende immigrasjon fra land der omskjæring av kvinner praktiseres, må slike svulster vurderes som differensialdiagose også i Norge ved tumor og smerter i vulva.

\section{Hjalmar A. Schiøtz \\ s-schi@online.no \\ Tonje Bohlin \\ Kvinnesenteret \\ Tor A. Klingen \\ Tor Aaberg \\ Avdeling for patologi \\ Sykehuset i Vestfold}

Pasienten har gitt samtykke til at artikkelen blir publisert.

Hjalmar A. Schiøtz (f. 1949) er dr.med. og spesialist i obstetrikk og gynekologi, med spesialkompetanse i urogynekologi. Han er seksjonsoverlege ved Kvinnesenteret.

Forfatter har fylt ut ICMJE-skjemaet og oppgir ingen interessekonflikter.

Tonje Bohlin (1979) er lege i spesialisering ved Kvinnesenteret.

Forfatter har fylt ut ICMJE-skjemaet og oppgir ingen interessekonflikter.

Tor A. Klingen (f. 1960) er spesialist i patologi og overlege ved Avdeling for patologi. Forfatter har fylt ut ICMJE-skjemaet og oppgir ingen interessekonflikter.

Tor Aaberg (f. 1953) er spesialist i patologi. Forfatter har fylt ut ICMJE-skjemaet og oppgir ingen interessekonflikter.

Litteratur

1. Female genital mutilation. WHO Fact sheet 241, 2010. www.who.int/mediacentre/factsheets/fs241/ en/ (9.2.2012).

2. Epstein D, Graham P. Rimsza M. Medical complications of female genital mutilation. J Am Coll Health 2001; 49: 275-80.

3. Vangen S, Hoffmann R, Flo K et al. Omskjæring av kvinner - komplikasjoner og behandling. Tidsskr Nor Lægeforen 2006; 126: 475-7. 
4. Osifo OD. Post genital mutilation giant clitoral epidermoid inclusion cyst in Benin City, Nigeria. J Pediatr Adolesc Gynecol 2010; 23: 336-40.

5. Rouzi AA. Epidermal clitoral inclusion cysts: not a rare complication of female genital mutilation. Hum Reprod 2010; 25: 1672-4

6. Fernández-Aguilar S, Noël J-C. Neuroma of the clitoris after female genital cutting. Obstet Gyneco 2003; 101: 1053-4

7. Craven EM, Bresnahan K. Neuroma of the clitoris. Del Med J 1983; 55: 341-2.

8. Ruud E. Nevrofibromatose 1 - så lett å diagnostisere, men så vanskelig? Tidsskr Nor Lægeforen 2002; 122: 2484

9. Cheng WC. Nerve tumour of the clitoris. Report of a case and commentary. J Obstet Gynaecol Br Commonw 1966; 73: 1016-7.

10. Migliorini A, Amato G. In tema di patologia neoplastica della vulva: raro caso di neurinoma del clitoride. Minerva Ginecol 1978; 30: 543-5.
11. Huang HJ, Yamabe T, Tagawa H. A solitary neurilemmoma of the clitoris. Gynecol Oncol 1983; 15: $103-10$

12. Thomas WJ, Bevan HE, Hooper DG et al. Malignant schwannoma of the clitoris in a 1-year-old child. Cancer 1989; 63: 2216-9.

13. Nishimura K, Sugao H, Sato K et al. Neurofibroma of the clitoris. A case report. Urol Int 1991; 46 : $109-11$.

14. Llaneza P, Fresno F, Ferrer J. Schwannoma of the clitoris. Acta Obstet Gynecol Scand 2002; 81: 471-2

15. Chuang WY, Yeh CJ, Jung SM et al. Plexiform schwannoma of the clitoris. APMIS 2007: 115: 889-90.

16. Yegane RA, Alaee MS, Khanicheh E. Congenital plexiform schwannoma of the clitoris. Saudi Med J 2008; 29: 600-2.

17. Sonnendecker EWW, Cohen RJ, Dreyer L et al. Neuroma of the vulva. A case report. J Reprod Med 1993; 38: 33-6.
18. Lefhalm B. Fleckenstein G, Kuhn W. Neurom im Bereich einer Episiotomienarbe. Eine Fallbeschreibung. Geburtshilfe Frauenheilkd 1996; 56 : $566-8$.

19. Dharmarathna HM, Tripathi N, Atkinson P. Painful, traumatic neuroma of an episiotomy scar: a case report. J Reprod Med 2007; 52: 456-7.

20. Vernadakis AJ, Koch H, Mackinnon SE. Management of neuromas. Clin Plast Surg 2003; 30: 247-68, vii.

Mottatt 9.11. 2011, første revisjon innsendt 28.1. 2012, godkjent 9.2. 2012. Medisinsk redaktør Jon Amund Kyte. 